\title{
The Choice of Teaching Contents and Course Arrangement of Universities TESL in Our Country
}

\author{
Yuan Xu Yan ${ }^{1, a}$ \\ Department of English, Tianhe College Of Guang Dong Polytechnic Normal University \\ Guangzhou, Guangdong, 510000 China \\ 164321098@qq.com ${ }^{2}$
}

Keywords: TESL, teaching contents, course arrangement.

\section{Abstract}

With the popularization of the teaching of English as a second language teaching model, many universities have set up the TESL course of teaching. Based on the introduction of the current situation of implementation in university TESL teaching of our country, in view of the teaching inefficiency, students unenthusiastic, curriculum unreasonable and so on, which exists in university TESL teaching in China.

This paper analyzes the improved ways of the choice of teaching contents and course designing in university TESL teaching of our country, that is re-positioning TESL teaching goal, optimizing teaching content structure; Taking a step by step teaching method, improving the teaching efficiency; Stressing practicality, and utility, improving the setting of the TESL teaching course.

\section{Introduction}

TESL(Teaching English As a Second Language, calling it TESL for short), meaning the teaching model of the learners who is not native English speakers but have many opportunities to be exposed to the environment of English language. Over the past decades, with the influx of more and more foreign immigrants and students who are non-native English speakers, American universities pay more attention to the teaching of TESL ${ }^{[1]}$.

In order to further improve the level of universities English teaching in China, this paper refers to the Universities TESL teaching mode of USA, and combines with the current situation of universities English teaching in China, introduces the TESL teaching of USA University to our country' college English teaching, it Plays an important role in helping improve the English Teaching level of universities in China ${ }^{[2] .}$

\section{The implementation of university TESL teachings}

The implementation of university TESL teaching in our country is mainly the introducing foreign teachers, creating language environment, implementing English teaching. With the further deepening of international cooperation and exchanges of teaching, the number of foreign teachers in English teaching of Chinese universities is increasing, so the introduction of foreign teachers has added new vitality to China's university English teaching ${ }^{[3] .}$

English is the mother tongue of foreign English teachers, and most of the foreign English 
teachers have standard language, speaks fluently and accurately, and they are familiar with

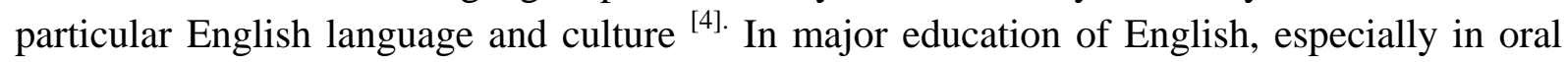
English teaching, they can be more effectively and skillfully to organize English teaching, help the students are immersed in English learning environment, and reduce the dependent of Chinese. Compared with the Chinese teachers, foreign teachers spoken more authentic standard, which is conducive to students learning. The students can directly feel the charm of English, the English vision of students is enlarged ${ }^{[5]}$. But that English teaching model also has some problems, the following mainly focus on analyzing the problems and countermeasures of university TESL teaching in our country.

\section{The existing problems of our country's university TESL teaching}

\section{A Teaching inefficiency}

The main reason about the low efficiency of our country's university TESL teaching is that, the unvaried material and the boring teaching and methods. For a long time, in our country each teaching stage, English teaching methods are backwardness, teaching content is inflexible, in the process of teaching English in the university, also exist such problems. This teaching mode and method is a static way of teaching, in the teaching process, the teacher is the subject, is an initiator of knowledge and experience, the student is the object, is a passive recipient of teaching content, all the knowledge and experience are passive completion, students have no interest in such a passive way of English teaching, even offensive.

In addition, with the expansion of student enrollment in recent years, the number of enrollment is rising, causing the qualities of students are uneven, so that English teaching in universities is difficult to achieve the ideal teaching effect. For years, although there are many schools and teachers in order to improve the students' interest in learning, improve teaching quality and teaching effect, and also adopt some corresponding measures, for example, the use of advanced teaching facilities, stimulating teacher-student interaction in classroom and so on, to assist complete the teaching task, but such teaching mode mostly just "same script, different cast”, it is unlikely to alter fundamentally, the corresponding teaching effect will not be much improved, and when work hard in school and try to this teaching mode, will be wasting a lot of time, the teaching efficiency is hard to be guaranteed.

In the aspects of foreign teachers, the hired foreign teachers in universities only understand western culture, but they know so little about Chinese culture, they have failed to understand China problem, they lack of understanding on Chinese culture and the students under the influence Chinese. The system of Chinese education and western education is different, under this system, students' learning motivation and purpose, teaching methods and means used by teachers, and the purpose of education are different. So foreign teachers' lack of understanding about the China culture, China conditions, and education system, which directly affects the foreign teacher's classroom teaching effect, and leads to teaching inefficiency.

\section{B Students unenthusiastic}

Now our university students are unenthusiastic on TESL teaching, there are a number of reasons for this: 
First, the students have unclear purpose of English learning. At present, a large part of college students don't know why to learn English, and do not know the importance of learning English. Just the course arrangement of school, then they have to go to class, learning, examination. They are entirely in a passive position. Teachers should help students realize the importance of learning English on their own development, and to help students to clear the purpose of learning English. Students to learn English actively, which is a prerequisite for them to learn English course.

Second, students lack of the enthusiasm for learning English. Some students are not high English level in preschool, and do not build up a solid foundation in English, so this contributes to a lack of enthusiasm in the process of English learning in the future, this is the widespread phenomenon among students study in colleges and universities at present, in addition to the pressure of obtaining the certificate, in the long time it will create a vicious cycle. Although, after the reform of the, it canceled the requirements about CET4 linked to degree certificate, but in a period of time, the employer still use the English level as one of the standards to employ, this is also one of the reasons for students unenthusiastic in learning English.

Third, students have no interest in the content of the classroom. At present the English examination committee of National University design and held CET4and CET6 test, Most of the universities to promote the students to learn English through this kind of examination, and to improve English level. But the class content is easily associated with examination. This kind of exam is the results of examination-oriented education, and this makes some school teacher to the classroom teaching focus on the one-sided pursuit of the high pass of examination-oriented education, it will objectively reduce the English application ability of students, the results just like many students said: "learning so many words and grammar, but no used, do not understand, can't say." Students have no real grasp of the use skills of language, but not really understand the true meaning of the language which is combined by Simple English words, not to mention the application ability in practice. Many college students face a strange language, lack of self-confidence; produce a kind of nervous fear. At the same time students think they have poor foundation, have a local accent, worry the pronunciation is substandard and expression is inaccurate, it will lead to students' English learning process always keep silent in the future, and have no interested in class. These conditions will inevitably hinder English practical application ability raise.

\section{Curriculum unreasonable}

Generally speaking, university teaching plan of TESL in our country has no fixed oral English textbooks; meanwhile teaching is lack of system and full of blindness. Many foreign teachers don't take textbook knowledge seriously, and many foreign teachers with all oral English class on their fingertips, no textbooks, no textbook, all the talk in class is a determination to run their own will, even teachers speak to their own, and students listen to their own. Some foreign teachers in oral English class, often learn Chinese, and communicate with students in Chinese, the teaching classroom change into a studying classroom. They are also lack of research on the teaching purpose and teaching task.

Because of the phenomenon of university teachers are less than student in our country, university English teachers in the process of teaching, facing the reality of more students, 
fewer hours, much of the teaching content. Therefore, in the compiling of English teaching materials, English teachers often focused on linguistic knowledge, discourse structure, the explanation of words and usage, in the teaching they will spend more time on the structure of the article and the grammar points, while students are busy with the understanding and remembering the content of teacher talk, no chance to use the spoken English to answer the teacher's questions..

Although some college textbook undergoes certain necessary changes, however, it's just a case of "same script, different cast", actually it have little real impact. Although many students can successfully pass the exam, but when using English to communicate with others they cannot open their mouth, after graduation to enter the society, these students will soon discover the gap between exam results and practical application, and have to spend spare time and energy on learning. Therefore, the disadvantages of English teaching materials, hinders the improvement of university English teaching quality to a large extent, also restricts the improvement of the overall level of university students' English.

\section{Paths of improving the choice of teaching contents and course arrangement of $T$ ELS}

\section{A Re-positioning TESL teaching goal, optimizing teaching content structure}

TESL should be introduced in our university English teaching, at the same time correct it as a dominant language for the service of western countries, replace the China culture English to introduce and Chinese elements of English Popularization, to promote and introduce China culture and China elements in English. The saving grace is that, our government has paid attention to the deep meaning of foreign language learning, from blind faith heart change into a sense of national pride and sense of superiority, with the help of English to transfer Chinese excellent culture, history and the achievements of reform and opening in thirty years to the world. China is exploring the adjustment of university entrance English examination, in the university English CET4 and CET6 test appearing the China elements of translating Chinese into English, which illustrates that Chinese is revising English Teaching deviation, stepping onto the path of the sustainable development of returning the intrinsic feature of language.

\section{B Taking a step by step teaching method, improving the teaching efficiency}

In the aspects of improving teaching methods, we can learn from America TESL teaching mode, first of all, English must be learned step by step, from easy to difficult. When students learn new content, if they have not learned the front, then they will feel more confused in the next. We often regardless of students' ability to accept, and blindly go on, so students will feel more and more difficult in learning, and even to the development of not listening, even they don't want to listen. Then every day before the end of the class, teachers need to fill out a feedback from which content is not difficult, just a few questions about the class, then let the students fill out it truthfully, so that teachers can learn what we have learned and mastered, in order to well adding and adjusting in second days.

The second is to active classroom atmosphere, and to explain lively. Try to organize some activities, which runs through the whole class, make the whole class interesting and lively. Before class, teachers should spend a lot of time to carefully preparing lessons, and provides 
the teaching plan, teaching program and teaching main content in this semester, which can query online for students; And in the classroom the teacher should let the students play a leading role; after-school teachers need to work flextime; Teachers can open blog and interact online with students, then understand the situation of students' learning, students can contact with teachers timely by telephone or other means of communication, and tell teachers what they want to hear, then make sure the students have the right to choose and the initiative. Our country university English teaching should makes learning English throughout the first and the second classroom of students, and makes sure the English teaching is continuous line; let teachers and students active interaction, maintain effective and lasting English joint of students in and outside class.

The last is to ensure that the class time, is not the more the better. The teacher in the input when the new knowledge to the students, to take into account the level of the students, not too much, not too little, and this is also what do not always notice. We always think about too little is bad for students, hope to change the original 40 minutes into 60 minutes. We pursuit of high capacity, thinking there will be good students can accept it, and not target to the most students, causing students polarization is very serious.

C Stressing practicality, and utility, improving the setting of the TESL teaching course Then we look at the famous textbook of TESL, the "Cambridge English", which is written in American English, consisting of student's book, teacher's book, exercise book, video, teacher resources, and teacher's resource book, Student's book sub unit by subject, each unit consists of two links, as shown in the table below:

Table1: the link classification of unit

\begin{tabular}{|c|c|c|c|}
\hline \multicolumn{2}{|c|}{ Student’s book } & \multirow{2}{*}{$\begin{array}{c}\text { Teacher's book } \\
\text { Test answer }\end{array}$} & \multirow{2}{*}{$\begin{array}{c}\text { Teaching material } \\
\text { Classroom listening materials }\end{array}$} \\
\hline The first link & The second link & & \\
\hline 1.Snapshot & 8.Dialogue & Teaching notes & Package of test level and assessment \\
\hline 2.Dialogue & $\begin{array}{l}\text { 9.Language } \\
\text { points }\end{array}$ & $\begin{array}{l}\text { Language points } \\
\text { summary }\end{array}$ & Video document \\
\hline $\begin{array}{l}\text { 3. Language } \\
\text { points }\end{array}$ & 10.Discussion & $\begin{array}{l}\text { Graphic data can be } \\
\text { copied }\end{array}$ & Optical disc \\
\hline 4.phonetic & 11.Hearing & the game can be chosen & $\begin{array}{c}\text { Interaction of network and complementary of } \\
\text { resources }\end{array}$ \\
\hline 5.New words & 12.Writing & & \\
\hline 6.Discussion & 13.nteraction & & \\
\hline 7.Hearing & 14.Read & & \\
\hline
\end{tabular}

The characteristics of this teaching material mainly has the following several points: First of all, in each unit the write four kinds skills training of listen, say, and read will appear at the same time. Secondly, it provides a large number of enlightening training methods and more listening, speaking, reading and writing practice opportunity. Third, emphasize the cultivation of communication ability, language training and teaching tasks throughout the teaching, grammar occupied space is limited. Fourth, language environment is rich and more realistic. Fifth, except for the classroom study, teaching materials can provide other information 
available for self-study or extracurricular learning and more reference materials. Compared with the Chinese teaching, the focus of these materials is listening, conversation, group activities, and training students' language communication ability.

English teaching of universities in China should learn USA University TESL teaching mode, take its teaching material as the standard, combining with China culture, to create a suitable materials for TESL teaching in China. Teachers should make every effort to create language learning environment for students, consciously cultivate the students' self-learning and lifelong learning ability. University English teachers should discard the rigid teaching mode of middle school, and inspire the student independently to find the answer to the problem. The cultivation of students' active learning should be always run through the whole teaching process, at the end of each semester each student's autonomous learning ability should be filed and graded, to summarize and classify the progress of student's autonomous learning situation.

Nowadays the cooperation and relationship between countries have become closer and closer because the tendency of the globalization becomes stronger and stronger, in the new period, English learning has been born out of the traditional "learn” stage, as a member of the global village, the students who have good professional knowledge of university should be aware of the purpose of English learning. Chinese gradually peaceful rise, also have more and more international discourse right, we must learn to make good use of English language communication, to promote China's peaceful ideas and development planning, using the China elements of English to depict the new issue of our English learning and the difficulties which is needed to overcome. We should to reform the present situation of our country university English teaching, emphasize the promotion of Chinese elements in English, and ensure the continuity of teacher and student interaction, surpass the examination-oriented education, help students develop the ability of self-learning and lifelong learning English ability.

\section{References}

[1] Zhang Zuo-tang, Zhang Zuo-chen. Analysis on course offerings and training Plans for MA program in TESL in the USA-Taking Minnesota state University, Mankato as an example. Journal of Bingtuan Education Institute, Vol 03, No.3, pp.55-58, 2007.

[2] Ji Shao-bin. Inspiration of TESL of American Universities to our college English Teaching-A case study of the language training center of university of Arizona. Journal of Wenzhou Vocational \& Technical College, Vol.14, No.1, pp. 85-88, 2011.

[3] Qian Xia-oxia, Jia Ai-wu. A review of ESL teachers' professional development in Canada. Studies in Foreign Education, vol.41, No.5, pp.82-90, 2014.

[4] Wang Chong, Cheng Yao-zhong. The curriculum and inspiration of the cultivation of the Canadian TESL teachers- A case study of the TESL project of university education of Mcgill University. Modern Primary and Secondary Education. vol.41, No.5, pp.121-125, 2014.

[5] Yang Hui. From the TESL materials to find out the American Chinese textbook compilation strategy. International Conference.vol 7, pp.222-228, 2010. 